\title{
FAIR AND EFFECTIVE USE OF PRESENT ANTITRUST PROCEDURE*
}

\section{By THURMAN ARNOLD $†$}

No GOVERNMENT policy has received such long and unquestioned public acceptance as that expressed by the Sherman Antitrust Act. The domination of market by small groups and the concentration of wealth and power in a few have been a matter of continuing public concern for over 40 years. However, in spite of a governmental religion officially dedicated to the economic independence of individuals, the growth of great organizations in America has been amazing. The Internal Revenue statistics for 1935 show that over $50 \%$ of all net corporate income is earned by less than one-tenth of $1 \%$ of the corporations reporting, and $84 \%$ of the aggregate corporate net profits is earned by less than $4 \%$ of the corporations reporting. We have become a nation of employees. Our private property, our security in our old age and the care of our families when we die usually consist of claims held directly or indirectly against great industrial organizations.

Our problem is therefore to define the public responsibility of such organizations, and to determine where industrial efficiency ends and industrial empire building begins. As a practical matter, indicated in the President's statement of February 18th, the question of prices overshadows the entire subject. We are accustomed to think of prices for building material, for aluminum kitchen utensils and for the various other things which are essential to decent living, as different.from taxes. But when these prices are set by a group which dominates the market, the only difference between such prices and taxes is the fact that such prices are levied without public responsibility or public control, and that their proceeds are used for private and not for public purposes. Mr. Justice Brandeis recognized this as early as 1922 when in The Ncze England Divisions Case $^{1}$ he called a railroad rate a tax. The failure of the public to realize that monopoly prices are taxes has been possible only because our peculiar mythology makes this sort of taxation by industrial organizations a more pleasant way of levying tribute than direct taxation by government, even though tribute when paid in the form of price runs only to the benefit of the few while when levied in the form of taxes it runs to the benefit of all. Yet the effect in reducing our individual incomes is even worse because such industrial prices so officially fixed are taxes levied on the rich and poor alike. And they are worse for another reason

*This paper was delivered before the Trade and Commerce Bar Association, New York, April 28, 1938.

† Assistant Attorney General of the United States.

1. 261 U. S. 184 (1923). 
because monopoly prices not only tax incomes but tend to destroy the sources of the incomes themselves.

The great mass of our population sell their goods, and services, and labor in the competitive markets. They buy their necessities in a controlled market. This is certainly at least one of the reasons why the income tax figures for 1935 show only 2,110,890 taxable incomes of over $\$ 2500$ for married persons and $\$ 1000$ for single persons in a nation of $130,000,000$. It is also at least one reason why, with the beginning of the depression of 1929 , the Brookings Institution showed that $21 \%$ of all American families had family incomes of less than $\$ 1000$ per year. To illustrate more concretely, we have charged the Aluminum Company of America with substantially complete monopoly control of the domestic source of raw material, coupled with practices which consolidate that monopoly. The result, in terms of prices, is this: Using 1926 as a base, aluminum prices receded from a high of 100 in that year to 84.9 in 19311933 , a decline in the depth of the depression of only $15 \%$. Meanwhile, to cite another metal, copper prices had dropped from 100 in 1926 to 40.3 in 1932, a decline of $60 \%$, four times the decline in the aluminum prices. And the entire combined wholesale index dropped $35 \%$ during the same period, more than twice the decline in aluminum prices. Again, in September 1937, two government invitations for bids on Ford size $6.60 \times 164$-ply tires resulted in an identical price of $\$ 8.11$ from all bidders. Investigation was instituted by the Department of Justice. When new bids were taken by the government a remarkable change had taken place. Instead of being identical the bids were competitive. Instead of $\$ 8.11$ the low was now $\$ 4.75$. In the meantime the public prices had not substantially varied.

All this by way of introduction, and I will not pursue these observations further because they have been made before. In general, however, I think we can agree that an efficient industrial organization is one capable of producing goods in quantities sufficient and at prices low enough to insure them a permanent place in an American standard of living. This means that whenever competition is destroyed there is no alternative except to interfere with and regulate arbitrary power to maintain rigid prices. In other words, monopoly means, sooner or later, government interference in business. I am willing to face that problem when the need arises. Yet it is precisely because $I$ do not wish those areas of necessary interference to increase and because I want to keep the government out of business that $I$ am an advocate of the consistent enforcement of the Antitrust Laws.

Today the monopoly problem has become so acute that the President has suggested the need for strengthening the Arititrust Laws and for new legislation relating to an antitrust policy. I am not, however, going to talk this evening on the Antitrust Laws as they should be. That 
problem is before Congress. I am going to speak on the Antitrust Laws as they are, which is the only present problem before the Department of Justice. In my recent book, "The Folklore of Capitalism," I have suggested that while past enforcement of the Antitrust Laws has saved us from recognizing the cartel system, it has not hampered the growth of organizations which dominate our industrial structure. One reason has been that we have treated the Antitrust Laws as a moral problem and have been more interested in pursuing the will-o'-the-wisp corporate intent than in determining violations of our anti-monopoly policy in terms of practical results. This is a matter of history. The assessment of the blame for what has happened in the past, while an interesting theological enterprise, gives no solution whatever. The duty before the Department of Justice is not to preach against the misdeeds of those who have gone before us, but to devise methods of utilizing the antitrust procedure which is at its disposal efficiently and fairly. That, therefore, is the subject of my address.

In discussing this problem I am going to be as definite and as explicit as I can. However, I know that you all realize that antitrust policy touches fields and boundaries which recede as you approach them and disappear each time you try to stake them out. Definiteness and precision in this area have been impossible even for the courts. It is even more impossible for the prosecuting arm of the government which is trying to follow a consistent policy of treating the mass of violations, not all of which can be prosecuted or even investigated. Yet none of the pressing problems of government can be solved by rule of thumb. This should not prevent us from being as definite and explicit as the nature of the question permits. Where the exercise of judgment and discretion is necessary, we can at least make public the grounds and the policy behind our use of that discretion. I will therefore discuss generally the considerations which underlie prosecution by the Department.

The first question of policy which I think should be publicly answered is why we ought not to exercise our judgment and discretion in slowing up antitrust prosecution during the present period of depression in order to give business the confidence to expand. The legalistic answer to that question is easy. It is found in our national belief in the efficacy of law enforcement as an end in itself.

A better answer is found in the examination of economic reality. It is my conviction that from a long range point of view the vigorous enforcement of Antitrust Laws is never more important than during periods of economic recession. Such periods give the larger and stronger firms new incentives and easier opportunities for extending their control over a narrow market. It is during these pericds that the smaller firms, wealsened by declining sales and profits, are most susceptible to destruction as the result of practices denounced by the Antitrust Laws. In other words, 
times of financial failure are the very times when persons with a thirst for power pick up the broken pieces of competing organizations and put them together. The clock can not be turned back when prosperity returns again. It is extremely difficult to recreate competitive organizations which have been destroyed because effective organizations are the result of habits and discipline and team work. Even the best baseball team after being disbanded for a year can not suddenly come together and win games. Organizations take time to build. They do not become efficient overnight. When they collapse it is anybody's guess whether they can be built up again. Therefore, the further an industry proceeds along the road to monopoly the more difficult is the application of the Antitrust Laws, for the reason that the Antitrust Laws in themselves can not rebuild the competitive organizations which have been destroyed.

We recognize that competition may be destroyed not only by active suppression; it may also be destroyed by the over-competition resulting from a temporary over-supply and a catastrophic price decline. Orderly markets are necessary in order to maintain the solvency of competitors. We must recognize that we are living in a world of competing organizations rather than competing individuals; that modern methods make mass production more efficient up to a certain point, and that an orderly market is required for the efficient distribution of goods. However, it is easy in times of depression to broaden the principles underlying the maintenance of orderly markets until they become an excuse for industrial empire building. In the prosecution by the Department of Justice this danger must be kept in mind. There are pressures peculiar to times of depression to maintain former high prices by agreements to restrict production on the principle of the necessity of an orderly market. We naturally can not sanction such distortions of a beneficent principle.

A second question of policy important in the antitrust cases is the recognition that results in restraint of trade are more important than the intent which lies behind them. In facing the difficult problem of determining whether size has gone beyond efficiency and has resulted in domination, or in the equally difficult question of whether a particular situation requires the application of a principle of an orderly marketing, little light is shed by discussing the problem on moral grounds. The difficulties in enforcing the antitrust laws due to the search for that fictitious thing known as corporate intent are set out in Attorney General Cummings' report for 1937 :

"Such a standard [the standard of corporate intent] is not only vague but it does not permit consideration of the real factors involved. It does not face the issue whether a combination is in fact one which will tend to produce economies of size or whether it will in actual operation tend to give an opportunity for monopoly profits. The important factor is taken to be the 'intent' or 'state of mind' 
of a fictitious corporate individual. Practical results of combinations, which are the only real criteria for effective, as distinguished from sentimental, administration of a policy to encourage competition, are brushed aside. We do not mean that from the multitude of conflicting precedents this statement can be made as a matter of strict legal definition. Nevertheless, it does accurately describe an attitude commonly taken by courts, emphasizing moral culpability and subordinating practical effects of business activities which tend toward monopoly or restraint of trade. . . .

"In other words, actual results are ignored in an effort to determine whether a fictitious personality is acting in an evil state of mind. The antitrust laws have become theological tracts on corporate morality." 2

These statements reflect my own present opinion. It is therefore my belief that in the selection of cases and also in the trial and presentation of cases we should formulate our standard in terms of the actual results and use of legal privileges by groups in achieving domination of the market rather than their motive. I will illustrate by the case of Interstate Circuit $v$. United States, recently argued before the Supreme Court of the United States. A first-run motion picture exhibitor, controlling seventy-five percent of the moving pictures in Texas, had entered into practically identical contracts with the major motion picture distributors which prevent second-run theatres from obtaining the best pictures except at higher admission prices than they had been accustomed to charge. Here was a typical use of a legal privilege (the copyright) in such a way as to restrict the outlets for moving pictures and actually to destroy competition. High admission prices were maintained and picture theatres put out of business. The moral question in the case was whether a conspiracy existed. To solve this it was necessary to see the shadowy line where a conspiracy ends and good fellowship and coöperation begins. Observe how the question proposed in another way admits a more practical answer. Is the use of the privilege given by the copyright laws by a group which actually dominates the market an effective suppression of competition regardless of whether a conspiracy is proved? The fact that picture houses have been closed and the distributing market has been narrowed by the use of this privilege on the part of a dominating group is certainly one of the most important factors in determining whether such a use of the copyright is illegal. It does not give a rule of thumb but it is at least more susceptible of critical examination than whether the group is acting in an evil state of mind. The particular case has not been decided as this is written. ${ }^{3}$ However, these considerations were argued strenuously by the

2. Annual Report of the Atrorney General of the United States (1937) 39.

3. The Supreme Court recently remanded the case to the district court for formal findings of fact and a separate statement of conclusions of law. Interstate Circuit, Inc., v. United States (1938) 5 U. S. L. WEEK 1028. 
Solicitor General and they should be argued in future cases. The Department does not of course control the decisions of the court, but in that area which it does control, that is, in the selection of the cases which are to be prosecuted out of a large number of complaints, only some of which is it even possible to investigate, actual monopoly results should be a more important consideration than motive.

A third question of policy concerns the choice between the civil and criminal procedures. It is my belief that under the present laws the most effective deterrent lies on the criminal side of the court, in so far as the prevention of illegal practices is concerned. I am talking about the situation as it now exists. I am aware that there are difficulties in a system which presents issues of extreme complication to jurors. I do not deny that by amendment changes might not be wrought upon the civil procedure which would make me modify my present position. However, I am not now discussing amendments, but the use of the tools which are now at hand.

I can make clearer the advantages of the criminal procedure by using an analogy. Violation of antitrust laws is more like the crime of reckless driving under pressure of haste or necessity than it is like conduct indulged in by those who are commonly called criminals. Take the familiar case which is repeated constantly in this country of a young man with respectable background with every expectation of a useful and brilliant career, who, in order to meet a social engagement, exceeds the speed laws and kills a pedestrian. There is no way before the jury verdict is handed in to predict whether he will be held guilty of manslaughter. His friends may hope for acquittal and believe that his conduct lies on the side of carelessness rather than recklessness. Nevertheless, no one would deny that such cases should be vigorously prosecuted. No one would assert that the prosecuting attorney should evade his responsibility to submit such issues to a jury. No one would pretend that an injunction which prevented the young man from doing it again would be an effective way to solve the problem of the reckless driver who may, in spite of his respectable background, be more dangerous to society than the burglar.

This is the kind of a crime committed by those who violate antitrust laws, under various business pressures to expand and to get as much of the market as possible. Such pressures can only be offset by a deterrent involving the risk of social stigma. It is as impossible for the Antitrust Division to detect or prosecute all of the violations of the antitrust laws as it is for any police force to detect and prosecute all the persons who drive sixty miles an hour. It is therefore necessary that business men realize that when they indulge in a doubtful practice they are taking the chance of something more than an injunction. They must not be permitted to weigh the chance of pecuniary liability against the chance of enormous profit, and government injunctions do not even involve pe- 
cuniary liability. This does not mean that instances will not be found where men who have recklessly or carelessly violated antitrust laws are not entitled to individual sympathy because of their unfortunate predicament. Nevertheless, the public should realize that without this kind of a deterrent the antitrust laws are useless.

The efficacy of the criminal penalty is illustrated in many cases which have been brought to my attention where corporate directors are willing to spend large sums of money belonging to the corporation in order to avoid the social stigma of a small individual fine. The ineffectiveness of civil prosecutions is illustrated by the fact that many of them assume almost the appearance of unemployment relief for attorneys, or distribution of patronage by the corporation. During such battles attorneys live magnificently. When a complicated decree is finally rendered a new scheme is often set up designed to appear plausible under the terms of the decree. A new suit is filed. By that time the actual persons who violated the law have sold their stock and are quite ready to accept a consent decree.

A fourth question of policy deals with the use of the civil and criminal proceedings concurrently, and in obtaining a consent decree in cases where the final outcome of the criminal case is uncertain, and relief to competitors and to the public is even more important than punishment of offenders delayed by long trials and appeals. It is the position of the Department that it was the intention of Congress in providing these two concurrent penalties that they could be used. In spite of the confusion recently created, the law on this point is, I think, clear. I know of no ethical policy which contradicts the plain provisions of the act of Congress or which forbids criminal prosecutions while negotiations for the consent decree are pending. However, the test of a consent decree obtained under such circumstances must be relief to the public which would be denied by delay. It should not be on the basis on which private litigation is compromised. One is concerned with the past; the other with the future.

The fifth question of policy which I wish to discuss is in some respects most important of all. It concerns making public the decisions and attitudes of the Department of Justice in the selection and prosecution of cases. The aim of such a policy is to give business men both guides and warnings in a field which is as admittedly uncertain in definition as the conception of reckless driving on the highway. The reason for such a policy is that there is no way that I know of to avoid the use of discretion and judgment in the conduct of the Antitrust Division. All complaints can not be prosecuted. A selection must be made. Therefore, the grounds underlying that selection should be publicly stated in each case to the end that a consistent and open policy of prosecution may gradually be derived from statements in connection with individual cases.

In the past there has been no continuing practice of announcing at the initiation of each prosecution why that particular prosecution was brought. 
The complaint itself directed at the narrow issue of the case is not a sufficient guide, because legal strategy necessarily plays a large part in its draftsmanship. It is a well known fact that business men have always found difficulty in interpreting the policy of the Department of Justice. The need for information on its policy is evidenced by the countless memoranda which are submitted to the Department in the hope of getting some indication of the Department's attitude. The rulings of no other department can give that information, because it is what the Department of Justice is going to do, and not what other departments think, which is important to business men. There is no reason why information as to the policies of the Department of Justice, so long as it does not involve the granting of individual immunity, should not be available to business men. The distribution of that information would be of advantage to both sides. So far as the government is concerned, it would prevent the argument of acquiescence in the cases where the government has not actually prosecuted. So far as business is concerned, it should be both a warning and a guide, because it would localize the Department's interpretation of the law to a particular industry. Obviously, however, it is unsafe to convey that information by promises of immunity to individuals on the bases of the data which they submit. The first step by a large organization in a plan of monopoly control is often the first move in a chess game and the player on the opposing side can not possibly guess the strategy behind it. There is no way of telling whether or not the particular data submitted is a Trojan horse.

The only safe way of building up information as to Department attitudes and policy is through announcements made at the beginning of each procedure, whether it be an investigation or an indictment, or a civil prosecution. Such an announcement might contain general information of how the Department is going to apply antitrust principles to a localized situation: (1) the summary of conditions the Department believed to exist in the particular industry which tended toward the violation of the antitrust laws and created the necessity of an investigation; (2) the reason why the particular procedure, whether civil or criminal, was chosen instead of some other kind of procedure; (3) the results the Department hopes to obtain in the prosecution of a particular case.

Let us apply such an announcement of policy to a hypothetical case which is designed to illustrate a number of different types of problems. Suppose the X company has over a period of years crushed competition in its industrial area until there is little likelihood of reviving it by the enforcement of an antitrust decree. Suppose that during the past twenty years there has been such governmental acquiescence in this process that as a practical matter criminal prosecution would be unsuccessful. Suppose the attention of the Department is called to an additional expansion of 
the $\mathrm{X}$ company which will swallow up one of the few remaining competitors and that civil suit is authorized.

To explain its policy in bringing that suit, the Department might publish a careful analysis giving first, the conditions in the industry, second, the reason for its selection for a civil prosecution, and third, the economic result it hopes to accomplish. In this particular hypothetical case, assume that no far reaching economic results would be expected. It should then be frankly stated that the reason for bringing the suit was to put the $X$ company on notice that no further acquisitions would be tolerated. This would at least lay the foundation for a criminal prosecution for a repetition of such conduct in the future. The report might then go on to state that structure of the $\mathrm{X}$ company is in itself a violation of the antitrust laws, but that in view of the improbability of recreating within a reasonable period of time by antitrust prosecution the competition which has been destroyed, the Department was using its personnel to push cases under which greater economic results would be expected. This would not be a waiver of the antitrust laws or agreement of immunity. It would only be a reason for the present determination to prosecute, given in public and subject to criticism and to revision by Congress. In the particular hypothetical case, the report might contain data from which Congress could further investigate the conditions and devise more effective techniques than those now available for meeting such situations. If the Department was wrong in its conclusion, it could be brought before the bar of congressional judgment.

After such a report, any business man connected with the industry could make an informed judgment about the interpretation of the Antitrust Laws by the Department in that particular area.

If each important suit were prefaced by such a statement of policy there would be built up gradually within the Department a reasonably consistent policy which would be a matter of public record. More consistency in the changing personnel of the Department might be expected to follow because it is a habit of human institutions to follow a pattern which they have publicly accepted. If changes were made, cogent reasons would have to be developed. If the policy was wrong it could be corrected.

This seems to me to be the only solution to the problem of bringing the present concealed process of the necessary selection of cases out into the open where it can be a guide and a warning. General provisions and formulae can never eliminate the use of discretion and judgment because the fundamental distinctions between efficient size and monopoly control and between the maintenance of orderly market and industrial empire building are too vague. They can become concrete only where they are localized and applied to conditions of a particular industry. No rule which has to apply to completely unlike conditions under dissimilar situations 
can ever be more than the statement of an ideal. We already have complete public acceptance of the ideal. What we lack is a series of public applications of that ideal to particular industries which will give it more definite application.

I conceive of the duty of the Department of Justice both to the courts and to Congress. To the courts they owe the duty of fair and able presentation of the particular cases which they prosecute. To Congress they owe the duty of marking out an intelligible line of policy of law enforcement. No other department can possibly outline that duty for them in a field where rules of thumb are not possible. Therefore, acting under the advice of the Attorney General, I propose to announce in connection with the particular cases or investigations which are instituted in the future enough information so that the exercise of the discretion in selecting the cases may be as consistent as public announcement and public criticism can make it.

As I said at the outset, I do not wish to confuse the discussion of fair and efficient enforcement of present Antitrust Laws with the problem of amendment, which is a separate problem. An analysis of what can be done with present procedure, however, throws incidental light upon the type of amendment which is most desirable. There are unquestionably better ways of investigation than by a grand jury. There are also means of implementing the civil process so that the criminal procedure will not be the only effective deterrent. An analysis of present procedure also indicates that the power of public investigation on the part of the Department might clarify the task of making its policy public and intelligible. These questions I leave for discussion at a later time. One aid to intelligent amendment can be accomplished by public statements in connection with individual cases. They can serve to call the attention of Congress to particular uses of legal privileges such as patents, copyrights, credit, corporate forms of organization, etc., which are being used in particular industries. Remedial legislation arrived at in that way would be definitely directed at particular problems. Such legislation is apt to be more concrete and more adapted to its ends than legislation which relies on general formulae. Our ideal is already well stated in the Sherman Law. It only requires particular application.

On examination by the Senate Committee I stated that I believed that antitrust enforcement should be both vigorous and fair. This paper has been an attempt to give content to those words. By a continuing policy of public statement when individual cases are commenced, I hope to make them even more concrete by giving them a particular application to the various dissimilar situations to which we must apply the general policies of the Antitrust Laws. The Antitrust Act represents a public policy to keep open and free the channels of opportunity, which has never been more important than today. 